\title{
Five-Year Growth of Rock Lichens in a Low-Arctic Mountain
} Environment, Northern Labrador

La croissance de lichens saxicoles sur une période de cinq ans en milieu montagneux subarctique, nord du Labrador Wachstum von Fels-Flechten in subarktischem Berg-Milieu, nördliches Labrador, über einen Zeitraum von fünf Jahren

\author{
R. J. Rogerson, D. J. A. Evans et W. D. McCoy
}

Volume 40, numéro 1, 1986

Premier symposium de la CANQUA

URI : https://id.erudit.org/iderudit/032625ar

DOI : https://doi.org/10.7202/032625ar

Aller au sommaire du numéro

Éditeur(s)

Les Presses de l'Université de Montréal

ISSN

0705-7199 (imprimé)

1492-143X (numérique)

Découvrir la revue

Citer cet article

Rogerson, R. J., Evans, D. J. A. \& McCoy, W. D. (1986). Five-Year Growth of Rock Lichens in a Low-Arctic Mountain Environment, Northern Labrador.

Géographie physique et Quaternaire, 40(1), 85-91.

https://doi.org/10.7202/032625ar
Résumé de l'article

En 1978, on a établi quatre sites de croissance du lichen dans la région du mont du Cirque dans les monts Torngat: trois sites des espèces Rhizocarpon de la section Rhizocarpon et un site de Alectoria miniscula. Cinq ans plus tard, en 1983, on a mesuré de nouveau les lichens pour constater que le diamètre moyen, qui témoigne de la croissance, a crû de manière très variable, soit de 0,10 à $0,54 \mathrm{~mm}$ par année. Ces taux de croissance sont plus élevés que prévu puisqu'ils dépassent de 3 à 20 fois les taux déjà mesurés dans le nord de la péninsule de Cumberland, île de Baffin. De tels taux de croissance du lichen s'apparentent davantage à ceux que l'on a observé dans les régions non arctiques au cours de sa période dite de grande croissance. Si ces taux s'appliquent à de longues périodes, il faudrait réévaluer la date de dépôt des moraines de récession dans les monts Torngat. Les moraines, que l'on croit dater de la période s'étendant du Wisconsinien supérieur à l'Holocène moyen, pourraient en fait dater du néoglaciaire. Toutefois, les variations observées entre les taux de croissance ne permettent pas d'utiliser ces données, même à l'échelle locale, pour tracer des courbes de croissance qui serviraient à établir des datations lichénométriques.
Tous droits réservés @ Les Presses de l'Université de Montréal, 1986
Ce document est protégé par la loi sur le droit d'auteur. L'utilisation des services d'Érudit (y compris la reproduction) est assujettie à sa politique d'utilisation que vous pouvez consulter en ligne.

https://apropos.erudit.org/fr/usagers/politique-dutilisation/ 


\section{FIVE-YEAR GROWTH OF ROCK LICHENS IN A LOW-ARCTIC MOUNTAIN ENVIRONMENT, NORTHERN LABRADOR}

R.J. ROGERSON, D.J.A. EVANS and W.D. McCOY; respectively: Departments of Earth Sciences and Geography, Memorial University of Newfoundland, St.John's, Newfoundland A1B 3X5; Department of Geography, University of Alberta, Edmonton, Alberta T6G 2H4; Department of Geology and Geography, University of Massachusetts, Amherst, Massachusetts 01003, U.S.A.

ABSTRACT In 1978, three lichen growth stations were established for Rhizocarpon section Rhizocarpon species and one for Alectoria miniscula in the Cirque Mountain area of the Torngat mountains. Five years later, in 1983, the lichens were remeasured. The five-year growth represented by the change in the theoretical diameter is very variable, between 0.10 and $0.54 \mathrm{~mm}$ per year. These rates are larger than expected and exceed rates previously determined for an eastern Arctic area, the Northern Cumberland Peninsula of Baffin Island, by more than 3 to more than 20 times. Similar rates are known for 'great period' growth outside Arctic regions. If the growth rates represent long-term growth, the ages of recessional moraines in the Torngat Mountains should be recalculated. Moraines formerly described as Late Wisconsin to mid-Holocene may be of Neoglacial age. Variability of growth rates from one individual to another precludes using these data for constructing growth curves which may be used, even locally, in lichenometric dating.
RÉSUMÉ La croissance de lichens saxicoles sur une période de cinq ans en milieu montagneux subarctique, nord du Labrador. En 1978, on a établi quatre sites de croissance du lichen dans la région du mont du Cirque dans les monts Torngat: trois sites des espèces Rhizocarpon de la section Rhizocarpon et un site de Alectoria miniscula. Cinq ans plus tard, en 1983, on a mesuré de nouveau les lichens pour constater que le diamètre moyen, qui témoigne de la croissance, a crû de manière très variable, soit de 0,10 à $0,54 \mathrm{~mm}$ par année. Ces taux de croissance sont plus élevés que prévu puisqu'ils dépassent de 3 à 20 fois les taux déjà mesurés dans le nord de la péninsule de Cumberland, île de Baffin. De tels taux de croissance du lichen s'apparentent davantage à ceux que l'on a observé dans les régions non arctiques au cours de sa période dite de grande croissance. Si ces taux s'appliquent à de longues périodes, il faudrait réévaluer la date de dépôt des moraines de récession dans les monts Torngat. Les moraines, que l'on croit dater de la période s'étendant du Wisconsinien supérieur à l'Holocène moyen, pourraient en fait dater du néoglaciaire. Toutefois, les variations observées entre les taux de croissance ne permettent pas d'utiliser ces données, même à l'échelle locale, pour tracer des courbes de croissance qui serviraient à établir des datations lichénométriques.
ZUSAMMENFASSUNG Wachstum von Fels-Flechten in subarktischem Berg-Milieu, nördliches Labrador, über einen Zeitraum von fünf Jahren. 1978 wurden im CirqueMountain-Gebiet der Torngat mountains vier Stationen zur Beobachtung des FlechtenWachstums eingerichtet: drei Stationen für Rhizocarpon-Arten der Sektion Rhizocarpon und eine Station für Alectoria miniscula. Fünf Jahre später, 1983, wurden die Flechten wieder gemessen. Der Fünfjahreswuchs, der sich im Wechsel des durchschnittlichen Durchmessers ablesen läßt, ist sehr unterschiedlich, zwischen 0.10 und $0.54 \mathrm{~mm}$ pro Jahr. Diese Wachstumsraten sind größer als erwartet und gehen über die zuvor für ein östliches arktisches Gebiet, die Nord-Cumberland Halbinsel der Insel Baffin, bestimmten Raten mehr als dreifach bis zu mehr als zwanzigfach hinaus. Ähnliche Wachstumsraten sind für die 'große Periode' des Flechten-Wachstums außerhalb der arktischen Gebiete bekannt. Wenn die Wachstumsraten LangzeitWachstum repräsentieren, müßte das Alter der Rückzugs-Moränen in den Torngat-Bergen neu berechnet werden. Moränen, die zuvor dem späten Wisconsin bis mittleren Holozän zugeschrieben wurden, könnten aus der Neoglazialzeit stammen. Die Variationen der Wachstumsraten von einer Person zur anderen schließen eine Nutzung dieser Daten zum Aufbau von Wachstumskurven aus, welche, selbst lokal, zur Datierung auf der Basis der Flechten benutzt werden könnten. 


\section{INTRODUCTION}

In the last 30 years, lichenometry has been widely used as a technique for relative dating of late Holocene events such as glacier recession (INNES, 1985a). Lichens are among the first plant forms to colonise newly-exposed rock surfaces and, since subsequent growth results in a relatively steady increase in the thallus size of individual lichens, lichen size is thought to be directly proportional to age. This relative dating technique may provide some absolute dates for geological events if the growth rate of the particular species of lichen is known for the area studied. Growth rates are very sensitive to climate and thus may vary significantly from place to place. They may be obtained indirectly by measuring sizes on substrates of known age, or directly by precise measurement of the same lichen thallus over time (LOCKE et al., 1979). In this paper the latter approach is taken in an attempt to redate glacier recession in an area of northern Labrador.

In early August 1978 four lichen growth stations were established and photographed at an altitude of $460 \mathrm{~m}$ and ca. $3 \mathrm{~km}$ northwest of Cirque Mountain $(1570 \mathrm{~m}$ ) in the Torngat Mountains of northern Labrador (McCOY, 1983) (Fig. 1). Station 1 had a single Rhizocarpon ${ }^{1}$ with a mean diameter of $50.6 \mathrm{~mm}$; Station 2 had three Rhizocarpon with mean diameters of 35.1, 27.5 and $17.8 \mathrm{~mm}$; Station 3 had three Rhizocarpon with mean diameters of 24.8, 24.9 and $17.5 \mathrm{~mm}$; Station 4 had a single Alectoria miniscula with a mean diameter of $68.6 \mathrm{~mm}$.

The stations are all located less than $100 \mathrm{~m}$ from the northeast corner of a distinctive lake (Fig. 1), in an area where McCOY reconstructed a local chronology of moraine abandonment based on minimum diameters of the largest lichens and an approximate growth rate of $.03 \mathrm{~mm}$ per year. This rate was developed by MILLER (1973) for northern Cumberland Peninsula, Baffin Island, but considered to be suitable as a preliminary growth rate for northern Labrador. The age of the lichen cover in the vicinity of the Stations was estimated to be $>4000$ years, based on the size of the largest lichens and Miller's growth rates. However, the individual lichens in the stations were smaller and were thought to vary from ca. 580 years to 1650 years in 1978, based on Miller's rates of growth. The objective of this paper is to apply the direct method for determining lichen growth rates to confirm or reject the use of Miller's rates in northern Labrador.

\section{METHODS}

McCoy's lichen growth stations were relocated and the individual lichens re-photographed with a $35 \mathrm{~mm}$ camera in late July 1983. As in 1978, care was taken to centre the

1. Following the suggestion of INNES (1985b), the lichens are identified by their section (Rhizocarpon) and series (Rhizocarpon) name since no laboratory identification is possible to determine if all are Rhizocarpon geographicum as reported in McCOY 1983. INNES (1985b) maintains that many lichenometric studies are of lichens which have been identified in the field only and when this is the case the term Rhizocarpon geographicum should not be used. lichens in the frame to minimize lens-edge distortion. A $1 \mathrm{~cm}^{2}$ or $4 \mathrm{~cm}^{2}$ scale was included in the same position in the photograph as in 1978. Negatives were produced and, using an enlarger to ensure accuracy, prints for both years were produced at identical scales. The thallus outlines, or prothalli, were traced and the 1978 outlines superimposed over the 1983 outlines. Clear differences between 1978 and 1983 lichen sizes are apparent in all cases (Fig. 2). The differences are concentrated neither around the lobes, nor in embayments on the prothalli, but are general to the whole outlines. Only the lichens at station 3 and 4 had parts of their prothalli which appeared unchanged between 1978 and 1983. In all these cases, the lengths of unchanged prothalli are less than onethird the perimeter length of the lichens concerned.

Lichen size has been measured in several different ways. To indicate the relative age of a substrate, it is usual to identify the largest thallus and to measure its diameter. Maximum, minimum, mean or modal diameters have been suggested (see LOCKE et al., 1979 and INNES, 1985a for full discussion). However, when lichen stations are established for construction of lichen growth curves, more precise measures of size are used. HOOKER and BROWNE (1977) developed a photogrammetric method, carefully making corrections for distortion, but determining size as the average of up to 16 lobe radii for an individual thallus. This is similar to the standard method described by LOCKE et al. (1979) which was used in this study for its simplicity. Individual lichen areas were measured using a precision co-ordinate digitizer, and mean theoretical diameters were calculated. Either change in theoretical diameter or change in areas can be used as measures of growth. Diameter is the more usual since results are directly applicable to the diameter measure of size used in lichenometric dating (INNES, 1985a).

\section{RESULTS}

Table I is a summary of the lichen growth data. Individual lichen thallus diameters increased between 0.10 and $0.58 \mathrm{~mm}$ per year for the period 1978-1983, with a mean increase for seven Rhizocarpon of $0.34 \pm .19 \mathrm{~mm}$ per year. The single Alectoria miniscula had a growth rate of $0.12 \mathrm{~mm}$ per year. Percentage increases in size ranged from $3.83 \%$ to $23.69 \%$ for Rhizacarpon, and $1.68 \%$ for Alectoria miniscula. They did not clearly vary with thallus diameter, although they showed some weak inverse relationship (Fig. 3d). In addition, no clear relationship between absolute increase in diameter and lichen thallus area in 1978 could be distinguished (Fig. 3c). An inverse relationship between any expression of lichen growth and initial (1978) size was expected since the 'great period' of growth of a lichen usually occurs in the first 50 to 500 years (LAWREY and HALE 1977). Also, the larger lichens were thought, by their size, to be beyond the 'great period', and in the 'maturation period' of linear growth. ARMSTRONG (1983) maintains that growth curves for Rhizocarpon geographicum differ from asymptotic curves of other lichens and diameter increase could approach zero at large diameters. 


\section{COMPARISONS AND DISCUSSION}

The measured rates of growth are much higher than those for the northern Cumberland Peninsula used by McCOY (1983). The maximum rate of $R$ hizocarpon growth measured $(0.58 \mathrm{~mm}$ per year) is closer to the 'great period' growth rates reported for Alpine Europe (BESCHEL, 1957), the Pacific Northwest (MILLER, 1969) and South Island, New Zealand (BURROWS and LUCAS, 1967) than those derived for most of Arctic Canada, including Baffin Island. Higher growth rates are known from Tunsbergdal in South Norway (MOTTERSHEAD and WHITE, 1972) and Wales (ARMSTRONG, 1983), but in both these cases the maximum rates of $0.9 \mathrm{~mm}$ per year were measured for small lichens approximately $20 \mathrm{~mm}$ in diameter. In Norway the rate decreased to $0.34 \mathrm{~mm}$ per year when the lichens reached a diameter of $65 \mathrm{~mm}$. MATTHEWS (1974) working in Jotunheimen, Norway, reports a rate of $0.75 \mathrm{~mm}$ per year at a size of $20 \mathrm{~mm}$, decreasing to $0.40 \mathrm{~mm}$ per year for diameters approaching $100 \mathrm{~mm}$.
In contrast to these, MILLER and ANDREWS (1972) report $0.15 \mathrm{~mm}$ per year until the lichen is ca. $15 \mathrm{~mm}$, subsequently decreasing to $0.03 \mathrm{~mm}$ per year on northern Cumberland Peninsula, Baffin Island. In Labrador, lichen growth could be similar to that described by BESCHEL (1961) for West Greenland where oceanic climates of the outer coast were thought to have higher lichen growth rates than the dry continental climates of the inner fiords.

LAWREY and HALE (1977) identify the four growth phases of lichens aș: a) juvenile phase, with a low rate of growth; b) 'great period', with a maximum rate lasting 50 to 500 years; c) maturation period of linear growth for $>1000$ years, to a maximum size for reliable dating (suggested as $75 \mathrm{~mm}$ by OROMBELLI and PORTER, 1983); d) senescence period of decreased growth, no growth (ARMSTRONG, 1983) or disintegration.

For Rhizocarpon geographicum, the passage from 'great period' to maturation is thought to occur when the thallus has

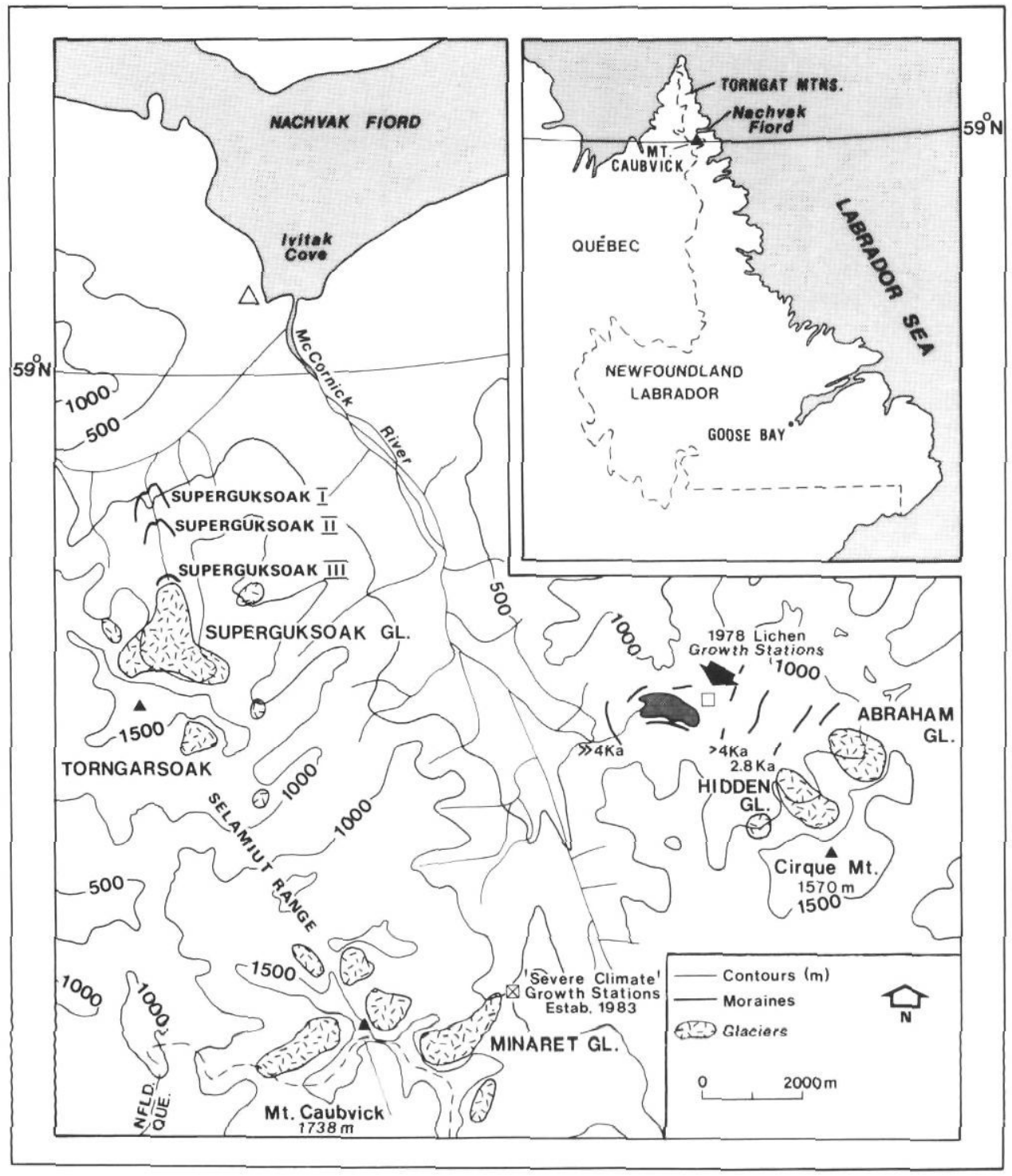

FIGURE 1. Location of lichen growth stations in northern Labrador and the moraines dated using lichenometry.

Localisation des sites de croissance du lichen et des moraines datées par lichénométrie. 


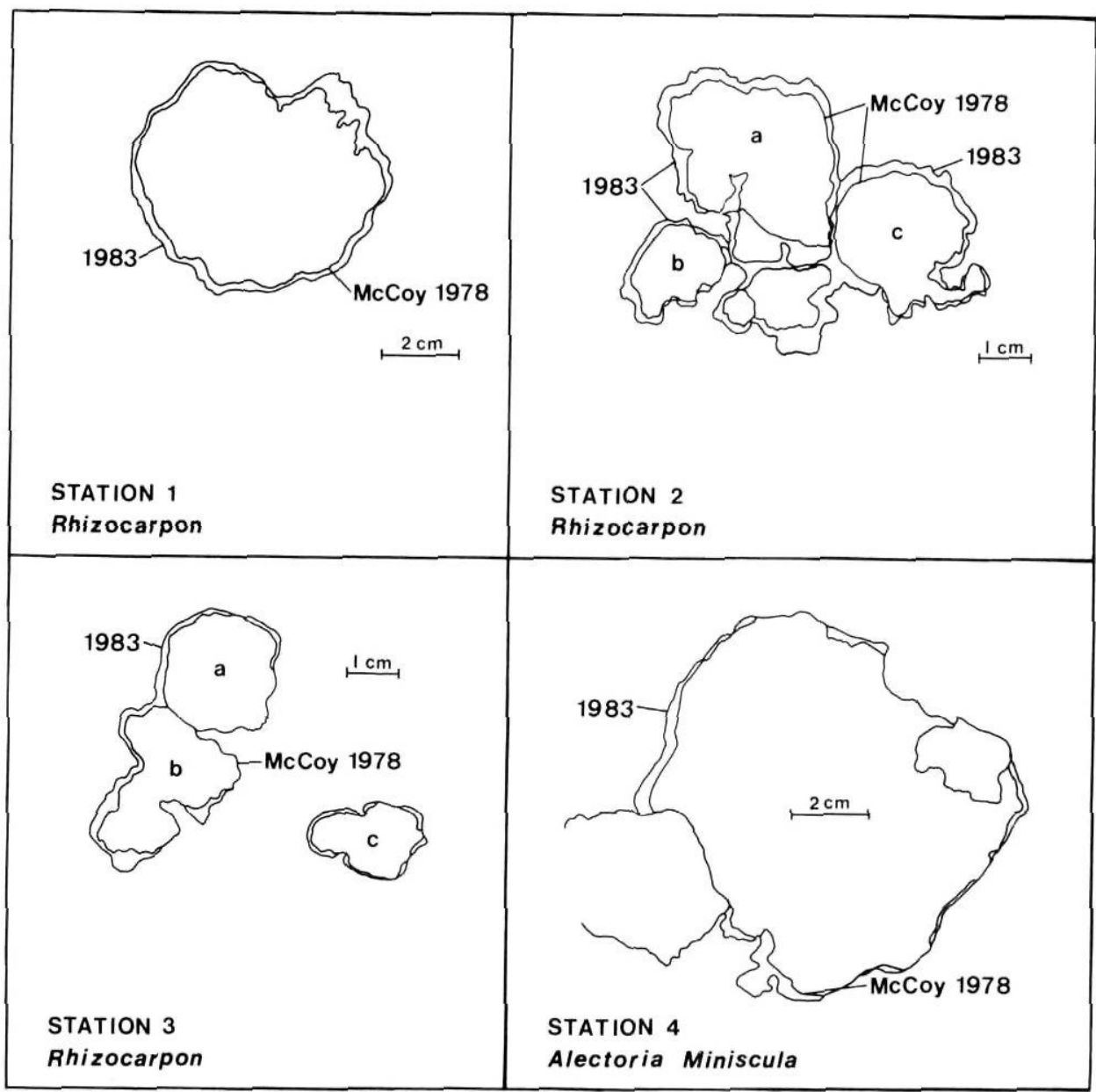

FIGURE 2. Outlines of lichens in 1978 and 1983 at four growth stations.

Contours des lichens observés en 1978 et en 1983 dans les quatre sites.

TABLE ।

Lichen Growth Data

\begin{tabular}{|c|c|c|c|c|c|c|c|c|}
\hline \multirow{2}{*}{ Station } & \multirow{2}{*}{ lichen } & \multicolumn{2}{|c|}{ Area $\left(\mathrm{cm}^{2}\right)$} & \multirow{2}{*}{$\begin{array}{c}\% \\
\text { growth }\end{array}$} & \multicolumn{2}{|c|}{ Diameter (mm) } & \multirow{2}{*}{$\begin{array}{l}\mathrm{mm} \\
\text { growth }\end{array}$} & \multirow{2}{*}{$\begin{array}{c}\text { Growth } \\
\text { (mm per year) }\end{array}$} \\
\hline & & 1978 & 1983 & & 1978 & 1983 & & \\
\hline 1 & Rhizo. & 20.10 & 22.32 & 11.04 & 50.6 & 53.3 & 2.7 & 0.54 \\
\hline $2 a$ & Rhizo. & 9.67 & 10.04 & 3.83 & 35.1 & 35.8 & 0.7 & 0.14 \\
\hline $2 b$ & Rhizo. & 2.49 & 3.08 & 23.69 & 17.8 & 19.8 & 2.0 & 0.40 \\
\hline $2 c$ & Rhizo. & 5.95 & 7.27 & 22.18 & 27.5 & 30.4 & 2.9 & 0.58 \\
\hline 3a & Rhizo. & 4.82 & 5.03 & 4.36 & 24.8 & 25.3 & 0.5 & 0.10 \\
\hline $3 b$ & Rhizo. & 4.87 & 5.65 & 16.02 & 24.9 & 26.8 & 1.9 & 0.38 \\
\hline $3 c$ & Rhizo. & 2.41 & 2.73 & 13.28 & 17.5 & 18.6 & 1.1 & 0.22 \\
\hline 4 & Al. min. & 36.95 & 37.57 & 1.68 & 68.6 & 69.2 & 0.6 & 0.12 \\
\hline
\end{tabular}

a diameter of 35 to $40 \mathrm{~mm}$ (PROCTOR, 1983). Only two of the Torngat stations had lichens greater than this size in 1978, yet one of those (Station 1) had the second highest growth rate measured (Table I).

The growth rates of the Torngat lichens appear to be typical of the 'great period'. This suggests that the lichens are younger than the 580 to 1650 years estimated from Miller's growth rates. 'Great periods' are believed to last from a few decades to about 500 years, and those with growth rates of approxi- mately $0.46 \mathrm{~mm}$ per year are usually associated with great period 'durations' of 100 to 300 years (WEBBER and ANDREWS, 1973).

Using the measured growth rates specific to the individual lichens, both the smallest lichen $(17.5 \mathrm{~mm})$ and the largest $(50.6 \mathrm{~mm})$ may have been approximately 90 years old, and the oldest lichen only 250 years old in 1978 . The mean growth rate of $0.34 \mathrm{~mm}$ per year would suggest an age of 150 years old for the largest lichen. 


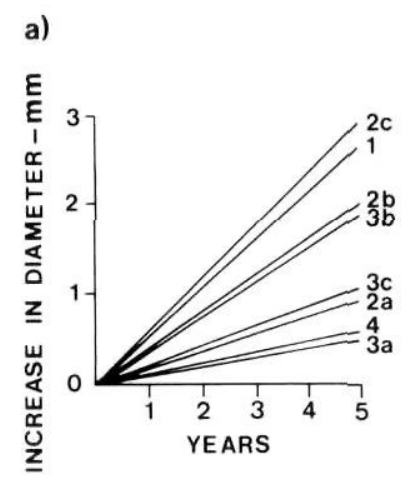

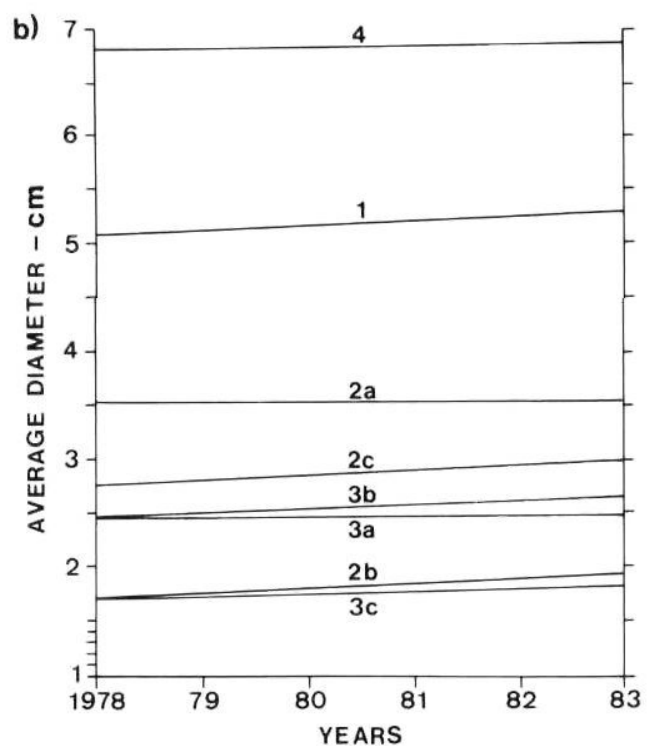

FIGURE 3. Graphic representations of statistics on lichen growth, 1978-1983: a) increase in diameter in five years; b) average diameters in 1978 and 1983; c) absolute increase in diameters as a function of lichen size (thallus area); d) percentage increase as a function of size.

Représentations graphiques des données statistiques recueillies sur la croissance des lichens de 1978 à 1983: a) accroissement du diamètre en cinq ans; b) diamètres moyens en 1978 et en 1983; c) accroissement absolu des diamètres en fonction de la taille des lichens (thalles); d) accroissement en pourcentages en fonction de la taille.
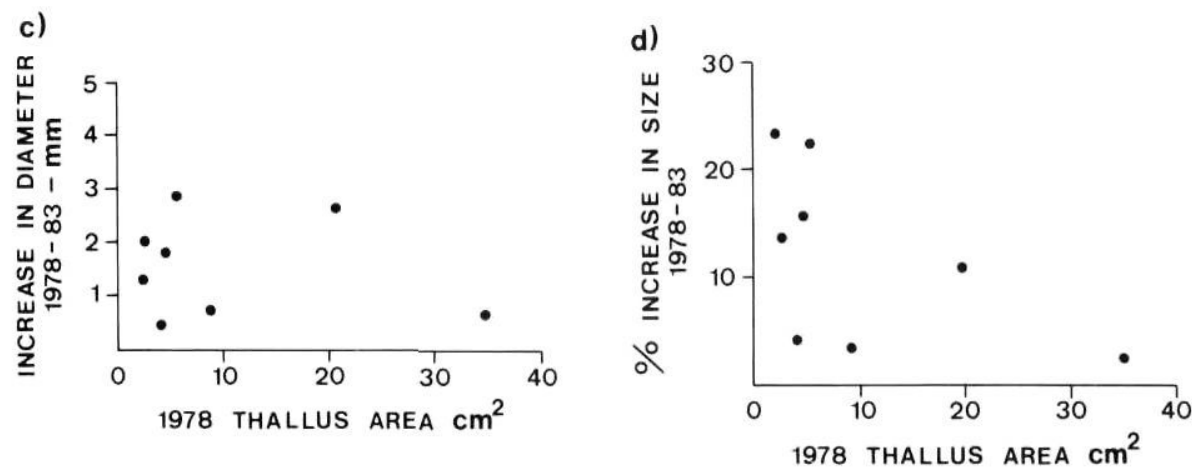

\section{REDATING GLACIER RECESSION}

If the measured rates of lichen growth are accepted as representing growth over a longer term than five years, it is reasonable to recalculate the dates of abandonment of moraines in the Torngat Mountains. Table Il outlines the differences between the ages calculated by McCOY (1983) for the Cirque Mountain area, from Miller's growth rates, and the ages calculated using the maximum, mean and minimum growth rates obtained in 1983. For further comparison, soils dating is included for the four oldest events using values of depth to the base of the B-horizon published by McCOY (1983), but not previously included in his chronology.

Scrutiny of air photographs taken in 1949 (LAB 48) and 1950 (LAB 92), approximately 30 years before the lichen stations were established, revealed that the ice margin at Abraham Glacier (Fig. 1) had not fluctuated by more than $20 \mathrm{~m}$. In 1949, ice covered the area formerly dated $<150$ years since deglaciation (McCOY, 1983), suggesting the recalculated mean age of 41 years is close to correct. This would also suggest the maximum growth rate in Table II is not likely correct.
Table III outlines the differences between the age of moraines in the Superguksoak Valley area (Fig. 1) according to Miller's growth rate and soils evidence (EVANS and ROGERSON, 1986), and the recalculated substrate ages based on the Cirque Mountain lichen growth rates.

The recalculations in Tables II and III challenge several earlier conclusions made on the deglaciation of the Torngat Mountains. The large moraine loops located within $5 \mathrm{~km}$ of the terminus of Abraham, Hidden and Superguksoak Glaciers would be of Neoglacial rather than Late Wisconsinan to Early Holocene age, based on the local rates of lichen growth. All the moraines in both areas could have formed within the last 1300 years. In both areas soils dating suggests earlier dates for the older events than does lichenometry. However, the rate of soil development (approximately $1.0 \mathrm{~cm}$ per thousand years) used both by McCOY (1983) and by EVANS and ROGERSON (1986), is taken from Baffin Island (EVANS and CAMERON, 1979), and from a preliminary curve of soil development, based on only two dates, in the Kangalaksiorvik area of Labrador, only $50 \mathrm{~km}$ to the north of the Cirque Mountain area (CLARK, 1984). Soil development, like lichen growth, 
TABLE ॥

A comparison between ages calculated from maximum thallus sizes and Miller's growth rates (McCOY, 1983), and ages calculated using the same sizes but maximum, mean and minimum growth rates measured from 1978-1983

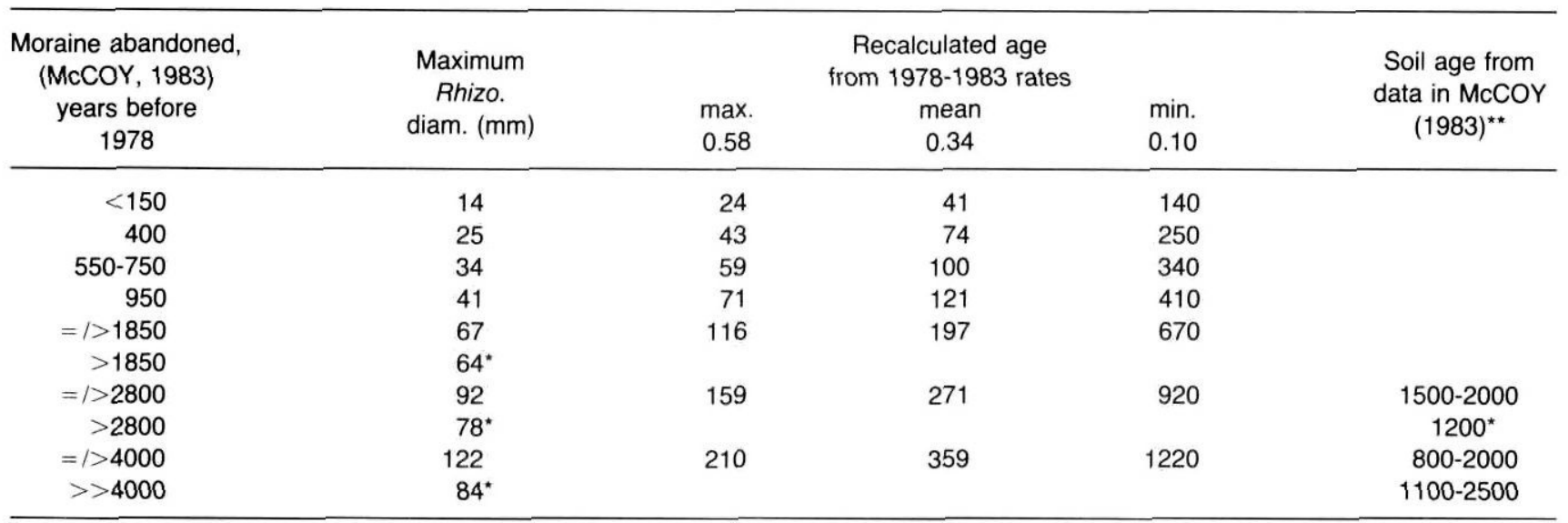

* Not indicative of true age as up-valley moraine has larger lichens or deeper soils.

** McCOY (1983) Table II, depth to the base of the B horizon (cm) times 100 (rate from EVANS and CAMERON, 1979).

TABLE III

Recalculation of the ages of glacial phases in the Superguksoak Valley, based on 1978-1983 lichen growth data.

\begin{tabular}{|c|c|c|c|c|c|c|}
\hline \multicolumn{2}{|c|}{$\begin{array}{l}\text { Phase and possible age } \\
\text { in years } \mathrm{BP}^{\star}\end{array}$} & \multirow{2}{*}{$\begin{array}{c}\text { Max. } \\
\text { Rhizo. } \\
\text { diam. } \\
\text { mm }\end{array}$} & \multirow{2}{*}{\multicolumn{3}{|c|}{$\begin{array}{cc}\begin{array}{c}\text { Recalculated age } \\
\text { using } \begin{array}{c}1978-1983 \text { rates } \\
\text { mean }\end{array}\end{array} & \text { min. } \\
58 & 200 \\
147 & 500\end{array}$}} & \multirow{2}{*}{$\begin{array}{c}\text { Soil } \\
\text { age in years } \mathrm{BP}^{\star}\end{array}$} \\
\hline Superguksoak III & 1500 & & & & & \\
\hline Superguksoak II & $3-5000$ & 90 & 155 & 265 & 900 & 5000 \\
\hline Superguksoak I & $5-12000$ & 100 & 172 & 294 & 1000 & 5000 \\
\hline
\end{tabular}

* EVANS and ROGERSON, 1986.

TABLE IV

Speculative rates of soil development based on 1978-1983 rates of lichen growth and $\mathrm{B}$ horizon depths obtained from closely-related soils

\begin{tabular}{|c|c|c|c|}
\hline $\begin{array}{l}\text { McCOY (1983) moraine } \\
\text { abandonment age } \\
\text { (years BP) }\end{array}$ & $\begin{array}{c}\text { Mean age } \\
\text { from Table II } \\
\text { (years BP) }\end{array}$ & $\begin{array}{l}\text { B horizon } \\
\text { depth } \\
\text { (cm) }\end{array}$ & $\begin{array}{c}\text { Rate of soil } \\
\text { development } \\
\text { (cm per } 1000 \text { years) }\end{array}$ \\
\hline$=1>2800$ & 271 & $15-20$ & $55-74$ \\
\hline$=1>4000$ & 359 & $8-20$ & $22-56$ \\
\hline \multicolumn{4}{|c|}{ EVANS \& ROGERSON phases, Table III age } \\
\hline Superguksoak III & $58-147$ & 0 & \\
\hline Superguksoak II & 265 & 5 & 19 \\
\hline Superguksoak I & 294 & 5 & 17 \\
\hline
\end{tabular}


may be more rapid in northern Labrador than it is on Baffin Island, which could mean that the soils-based ages are too great.

These data permit speculation on the rates of soil development required to provide a perfect agreement between lichenometry and soils dating in the Torngat. Table IV suggests that the rates would be 22 to $74 \mathrm{~cm}$ per thousand years for the Cirque Mountain area and $18 \mathrm{~cm}$ per thousand years for the Superguksoak area. These are very high rates of soil development, possibly a whole order of magnitude higher than any other Arctic locality, and may be unrealistic. Yet both lichen growth and soil development are functions of climate. The Torngat is an area of relatively long growing season, warm temperatures and high precipitation compared with most Arctic localities, and these are all factors likely to increase both lichen growth and soil development.

Perhaps the most significant result from this study is that large variations in short-term growth rates occur within a small area. These variations suggest that short-term measurements of lichen growth, with a time interval of five years, may be insufficient for constructing precise local growth curves, despite the claim that three growing seasons is a sufficient interval to average out anomalous summers (LOCKE et al., 1979). Nevertheless, growth rates determined by MILLER (1973) on the Cumberland Peninsula, Baffin Island, cannot be used for northern Labrador in view of the magnitude of growth from all direct measurements made in this study.

In 1983, further lichen growth stations were marked and photographed at a 'severe' climate site, at $900 \mathrm{~m}$ asl, near the terminus of Minaret Glacier (Fig. 1). Future remeasurement at these and the 1978 growth sites, may settle whether growth rates are also high and variable in a severe topoclimate, and whether growth remains highly variable over a longer time span. These are important questions in lichenometry where small differences in lichen sizes are often inferred to represent significant time intervals.

\section{ACKNOWLEDGEMENTS}

Remeasurement of the lichen growth sites in 1983 was supported by NSERC Operating Grant no. A6105 and EM\&R Research Agreement 283, both awarded to R.J. Rogerson. Field assistance was provided by Lloyd St.Croix. Two anonymous referees are gratefully acknowledged for their detailed reviews which changed and improved the original draft.

\section{REFERENCES}

ARMSTRONG, R.A. (1983): Growth curve of the lichen Rhizocarpon geographicum, New Phytologist, 94: 619-622.

BESCHEL, R.E. (1957) : Lichenometrie im Gletshervorfeld, Jahrbuch des Vereins zum Schutze Alpenflanzen und Alpentiers, 22: 164185.

(1961): Dating rock surfaces by lichen growth and its application to glaciology and physiography (lichenometry), in G.O. Raasch (ed.), Geology of the Arctic, Vol. 2, University of Toronto Press, p. 1044-1062.

BURROWS, C.J. and LUCAS, J. (1967): Variations in two New Zealand glaciers during the past 800 years, Nature, 216: 467-468.

CLARK, P. (1984): Glacial geology of the Kangalaksiorvik-Abloviak region, northern Labrador, Canada, Unpublished PhD Dissertation, University of Colorado, Boulder, Colorado, $240 \mathrm{p}$.

EVANS, D.J.A. and ROGERSON, R.J. (1986): Glacial geomorphology and chronology in the Selamiut Range/Nachvak Fiord area, Torngat Mountains, Labrador, Canadian Journal of Earth Sciences 23(1): 66-76.

EVANS, L.J. and CAMERON, B.H. (1979): A chronosequence of soils developed from granitic morainal material, Canadian Journal of Soil Science, 59: 203-210.

HOOKER, T.N. and BROWN, D.H. (1977): A photographic method for accurately measuring the growth of crustose and foliose saxicolous lichens, Lichenologist, 9: 65-75.

INNES, J.L. (1985a): Lichenometry, Progress in Physical Geography, 9 (2): $187-254$

(1985b): A standard Rhizocarpon nomenclature for lichenometry, Boreas, 14: 83-85.

LAWREY, J.D. and HALE, M.E. (1977): Studies on lichen growth rate at Plummers Island, Maryland, Proceedings of the Biological Society of Washington, 90: 698-725.

LOCKE, W.W. III, ANDREWS, J.T. and WEBBER, P.J. (1979): A manual for lichenometry, British Geomorphological Research Group Technical Bulletin, 26: 1-47.

MATTHEWS, J.A. (1974): Families of lichenometric dating curves from Storbreen gletschervorfeld, Jotunheimen, Norway, Norsk Geografisk Tidsskrift, 28: 215-235.

McCOY, W.D. (1983): Holocene glacier fluctuations in the Torngat Mountains, Northern Labrador, Géographie physique et Quaternaire, 37 (2): 211-216.

MILLER, C.D. (1969): Chronology of Neoglacial moraines in the Dome Peak area, North Cascade Range, Washington, Arctic and Alpine Research, 1 (1): 49-66.

MILLER, G.H. (1973): Late Quaternary glacial and climatic history of northern Cumberland Peninsula, Baffin Island, NWT, Canada, Quaternary Research, 3: 561-583.

MILLER, G.H. and ANDREWS, J.T. (1972): Quaternary history of northern Cumberland Peninsula, east Baffin Island, NWT, Canada, Part IV: preliminary lichen growth curve for Rhizocarpon geographicum, Geological Society of America Bulletin, 83: 11331138.

MOTTERSHEAD, D.M. and WHITE, I.D. (1972): The lichenometric dating of glacier recession, Tunsbergdalsbre, Southern Norway, Geografiska Annaler, 54: 47-52.

OROMBELLI, G. and PORTER, S.C. (1983): Lichen growth curves for the southern flank of the Mont Blanc Massif, Western Italian Alps, Arctic and Alpine Research, 15 (2): 193-200.

PROCTOR, M.C.F. (1983): Sizes and growth rates of the lichen Rhizocarpon geographicum on the moraines of the Glacier de Valsorey, Valais, Switzerland, Lichenologist, 15: 249-262.

WEBBER, P.J. and ANDREWS, J.T. (1973) : Lichenometry: a commentary, Arctic and Alpine Research, 5 (4): 295-302. 